\begin{tabular}{lll}
\hline NOMOR XXI (1) & April 2015 & Halaman 1-13 \\
\hline
\end{tabular}

\title{
PERAN BABINSA DALAM KEGIATAN DETEKSI DINI GUNA PENCEGAHAN AKSI TERORISME (RELEVANSI DI WILAYAH KODIM 0618/BS KOTA BANDUNG)
}

\author{
Komarudin Simanjuntak \\ Mabes Angkatan Darat \\ Email: wibisonoph9@gmail.com
}

\begin{abstract}
This study aimed to determined the role of non-commissioned officer in the early detection activities, constraints Babinsa role in the early detection activities and formulated efforts to optimized Babinsa role in the early detection of activities for the prevention of terrorism. Methods This study used a qualitative approach, with the data collection technique: First, theoretical orientation; collecting data with three stages, orientation, exploratory data collection, and research focus; Second, in-depth interviews and comprehensive; Third, the observation participation; and Fourth, documentation. In this study would be taken groups / people associated with problems Babinsa role in the early detection of activities to discovered problems in the field of the structural officials in institutional organization.

The results were expected to knew about the current objective conditions Babinsa role in the early detection activities at the level of understanding and awareness as well as its ability to helped prevention and control of terrorism in the region, as well as being able to identified the success factors in the activities of early detection as well as constraints in implementing the role seen on environmental aspects of security level. Then, about commitment and public awareness participating in the prevention and control of terrorism, by reviewing how institutional Babinsa accompanied by cooperation between the relevant authorities in handling the increasing role of Babinsa. Thus, could find the policy, strategy and efforts were enhanced through regular coaching related apparatus and increase the capabilities Babinsa role in the early detection activities, as well as the handling in helping the integration of prevention and control of terrorism.
\end{abstract}

\section{Keywords: Role of Babinsa, Early Detection, Terrorism}

\begin{abstract}
ABSTRAK
Penelitian ini bertujuan mengetahui peran Babinsa dalam kegiatan deteksi dini, kendala peran Babinsa dalam kegiatan deteksi dini dan merumuskan upaya optimalisasi peran Babinsa dalam kegiatan deteksi dini guna pencegahan aksi terorisme. Metode penelitian ini menggunakan pendekatan kualitatif, dengan teknik pengumpulan data: Pertama, orientasi teoritik; pengumpulan data dengan tiga tahap yaitu orientasi, eksplorasi pengumpulan data, dan penelitian terfokus; Kedua, wawancara mendalam dan komprehensif; Ketiga, observasi peran serta; dan Keempat, dokumentasi. Dalam penelitian ini akan diambil kelompok / orang yang terkait dengan permasalahan peran Babinsa dalam kegiatan deteksi dini untuk menemukan permasalahan di lapangan terhadap pejabat struktural dalam kelembagaan organisasi tersebut.

Hasil yang diharapkan untuk mengetahui kondisi obyektif saat ini tentang peran Babinsa dalam kegiatan deteksi dini pada tingkat pemahaman, dan kepedulian serta kemampuannya dalam membantu pencegahan dan penanggulangan aksi terorisme di wilayah, serta mampu mengidentifikasi faktor keberhasilan dalam kegiatan deteksi dini serta kendala dalam melaksanakan peran dilihat pada aspek tingkat keamanan lingkungan. Lalu, tentang komitmen serta kesadaran masyarakat berpartisipasi dalam membantu pencegahan dan penanggulangan
\end{abstract}


aksi terorisme, dengan meninjau kelembagaan Babinsa disertai dengan bagaimana kerja sama penanganan antar aparat terkait dalam peningkatan peran Babinsa. Sehingga, dapat menemukan kebijakan, strategi dan upaya yang ditingkatkan melalui pembinaan rutin aparat terkait dan meningkatkan kapabilitas peran Babinsa dalam kegiatan deteksi dini, serta keterpaduan penanganan dalam membantu pencegahan dan penanggulangan aksi terorisme.

Kata Kunci : Peran Babinsa, Deteksi Dini, Aksi Terorisme

\section{PENGANTAR}

\section{Latar Belakang}

Perkembangan terorisme di Indonesia sejak tahun 2001 sampai dengan 2013 cukup memprihatinkan, hampir setiap tahun ada aksi terror yang memakan korban baik korban luka-luka maupun korban tewas. Kegiatan teroris memaksa masyarakat untuk lebih waspada bila berada di tempat yang mencurigakan. Keresahan dan kewaspadaan akan mempengaruhi pola kehidupan masyarakat dalam berbangsa dan bernegara. Kejadian terorisme di Indonesia sejak tahun 2001 mulai dari Bom Gereja Santa Anna Jakarta, Bom Plaza Atrium Senin Jakarta. Tahun 2002, Bom Tahun Baru Jakarta, Bom gereja di Palu, Bom Bali, Bom Mac Donald Makasar. Tahun 2003, Bom Bandara Sukarno Hatta Jakarta, Bom JW Marriot. Tahun 2004, Bom Palopo, Bom Kedubes Australia, Bom Gereja Emmanuele. Tahun 2005, Bom Ambon, Bom tentena, Bom Pamulang, Bom Bali, Bom Palu. Lalu Tahun 2009, Bom JW Marriot dan Ritz Carlton. Tahun 2011, Bom Cirebon, Bom Gading Serpong, Bom Gereja Solo. Tahun 2013, Bom Bunuh Diri di Mapolres Palu. Semua kejadian teroris ini membawa korban jiwa yang tidak sedikit.

TNI AD sebagai instrumen negara di bidang pertahanan, melaksanakan tugas pokok melalui Operasi Militer Untuk Perang (OMP) dan Operasi Militer Selain Perang (OMSP). Tugas OMSP meliputi 14 tugas, salah satu tugas OMSP mengatasi aksi terorisme secara bersama-sama dengan seluruh komponen bangsa. (Departemen Pertahanan RI, 2008) Studi tentang penanggulangan terorisme di Indonesia telah banyak dikemukakan oleh para pakar dan juga dibukukan oleh para ahli atau akademisi, seperti Sekarwarsini Djelantik (2010), dalam buku Terorisme: "Tinjauan Psiko Politis, Peran Media, Kemiskinan, dan Keamanan Nasional". Menyampaikan tentang bagaimana kaitan terorisme dengan keamanan nasional, dan memberikan masukan mengenai upaya-upaya penanggulangan terorisme, khususnya di Indonesia.

Menyambung tentang terorisme, (Hendropriyono, 2009) dalam buku Terorisme : "Fundamentalis Kristen, Yahudi, Islam", menyiratkan bahwa dengan menggunakan teori filsafat Ludwig Wietgenstein, berusaha menemukan akar-akar terorisme yang antara lain terwujud dalam pola permainan bahasa teror yang khas, dan hanya lewat kajian filsafat maka dapat disusun metode, strategi, dan taktik yang tepat dalam usaha menumpas terorisme.

Wawan H. Purwanto (2009) dalam buku Terorisme: "Satu Dasawarsa Terorisme di Indonesia", menyampaikan gambaran tentang apa yang terjadi dalam berbagai aksi teror di tanah air terkait dengan memanasnya situasi dunia internasional. Penanganan aksi tindak kekerasan ini tidak bisa parsial, melainkan harus komprehensif dan saling bekerjasama antar komunitas internasional. Sarlito Wirawan Sarwono (2012) dalam buku: 
"Terorisme Di Indonesia Dalam Tinjauan Psikologi”, menyampaikan tentang dengan memahami kondisi psikologis para pelaku teror, menawarkan jalan altenatif untuk memutus mata rantai dan keberlanjutan.

Keempat buku tersebut diambil dan dijadikan pendukung utama sebagai tinjauan pustaka dalam gagasan penelitian tentang aksi terorisme yang dilaksanakan di wilayah Kodim 0618/BS Kota Bandung, seluruhnya membahas tentang aksi terorisme, namun masing-masing dengan titik berat pokok bahasan yang berbeda-beda, termasuk berbeda dengan pokok bahasan dalam penelitian yang telah dilaksanakan di wilayah Kota Bandung.

TNI AD dapat digunakan untuk mengatasi aksi terorisme dengan mengerahkan semua kemampuan (Intelijen, Tempur, Dukungan dan Pembinaan Teritorial) yang dimiliki TNI AD. Babinsa sebagai unsur terdepan dalam Pembinaan Teritorial Komando Kewilayahanan di lapangan, dalam melaksanakan tugas seharihari berusaha untuk membentuk jaringan Mitra Babinsa di kelurahan. Mitra Babinsa diharapkan menjadi ujung tombak deteksi dini dan upaya pencegahan teroris. Babinsa dan Mitra Babinsa setiap saat dapat melaporkan informasi yang berpotensi menimbulkan gangguan keamanan. Kondisi ini perlu didukung tingkat pemahaman, tingkat kepedulian dan tingkat kemampuan Babinsa dalam kegiatan deteksi dini, untuk membantu mencegah terorisme.

Tujuan penelitian : Untuk (1).Membahas dan mengkaji peran Babinsa dalam kegiatan deteksi dini. (2). Membahas dan mengkaji kendala peran Babinsa dalam kegiatan deteksi dini. (3). Membahas dan mengkaji upaya optimalisasi peran Babinsa dalam kegiatan deteksi dini guna pencegahan aksi terorisme.
Dalam penelitian ini, pemilihan subjek penelitian adalah informan sebagai sumber data untuk pelengkap kuisioner, yang dilakukan dengan model purposive sampling, yaitu dipilih dengan pertimbangan tertentu sesuai dengan tujuan penelitian. Berdasarkan pertimbangan dari tujuan penelitian yang dilakukan, informan dalam penelitian ini adalah Komandan Kodim, Perwira Staf Intel, Perwira Staf Administrasi dan Logistik, Perwira Staf Teritorial dan para Danramil di Kodim 0618/BS Kota Bandung, juga para tokoh masyarakat yang mempengaruhi peran Babinsa dalam kegiatan deteksi dini. Sedangkan objek penelitian adalah suatu sasaran ilmiah dengan tujuan dan kegunaan tertentu untuk mendapatkan data tertentu yang mempunyai nilai, skor atau ukuran yang berbeda yang akan dibuktikan secara objektif untuk mendapatkan data sesuai tujuan dan kegunaan tertentu. Adapun objek penelitian dalam penelitian ini yaitu kelompok responden yang terdiri dari para Babinsa dan para Mitra Karib yang mengisi kuisioner untuk dapat memberikan deskriptif kualitatif tentang peran Babinsa dalam kegiatan deteksi dini.

\section{PEMBAHASAN}

Dalam bagian pembahasan ini, akan disampaikan tentang Kondisi Geografi, Demografi dan Kondisi Sosial Wilayah Kodim Kota Bandung, Peran Babinsa Dalam Kegiatan Deteksi Dini, Kendala Peran Babinsa Dalam Kegiatan Deteksi Dini, Peluang dan Kendala serta Peningkatan Peran Babinsa Dalam Kegiatan Deteksi Dini.

Kota Bandung adalah ibukota Provinsi Jawa Barat dengan luas 16.729,65 Ha, yang berada pada koordinat $6^{\circ} 50$ ' $38^{\prime \prime}-6^{\circ} 58^{\prime}$ $50^{\prime \prime} \mathrm{LS}$ dan $107^{\circ} 33^{\prime} 34^{\prime \prime}-107^{\circ} 43^{\prime} 50^{\prime}$ " 
BT. Bentuk bentangan alam Kota Bandung merupakan cekungan dengan morfologi perbukitan di bagian Utara dan dataran di bagian Selatan. Secara morfologi regional, Kota Bandung terletak di bagian tengah "Cekungan Bandung", yang mempunyai dimensi luas $233.000 \mathrm{Ha}$. Wilayah kota bandung beriklim sejuk, di daerah pegunungan / dataran tinggi tekanan suhu pada siang hari rata-rata mencapai $22 \mathrm{s.d} 27^{\circ} \mathrm{C}$ dan malam hari berkisar $19 \mathrm{s.d} 22^{\circ} \mathrm{C}$. Untuk daerah dataran rendah pada siang hari berkisar $22 \mathrm{~s} . \mathrm{d}$ $24^{\circ} \mathrm{C}$ sedang untuk malam hari berkisar antara 24 s.d $26^{\circ} \mathrm{C}$. Tumbuhan (Flora dan Fauna), di bagian Utara dan Barat masih terdapat pohon-pohon besar sebagai pohon pelindung jalan. Di bagian Selatan dan Timur, sebagian tanahnya keras dan daerah pertanian.

Pelabuhan laut di wilayah ini tidak ada, sedangkan Pelabuhan Udara, lapangan udara nasional adalah Lanud Husen Sastranegara dan Lanud Sulaeman di Margahayu disempurnakan untuk kepentingan militer. Fasilitas lain seperti relay Televisi (TVRI) dan TV swasta lainnya telah dibangun. Untuk sarana peribadatan wilayah Kota Bandung memiliki Masjid sebanyak 2.563 buah, Gereja Kristen/Protestan sebanyak 57 buah, Gereja Katolik sebanyak 101 buah, Vihara sebanyak 148 buah dan Kuil sebanyak 5 buah.

\section{Kondisi Demografi}

Jumlah penduduk wilayah Kodim 0618/ BS 2.258.142 orang, kepadatan penduduknya mencapai 20.000 orang $/ \mathrm{km}^{2}$. Suku bangsa di wilayah ini mayoritas adalah golongan Sunda dan Jawa. Agama yang dianut di antaranya Islam sebanyak 2.022.831 orang, Kristen/Protestan sebanyak 105.376 orang, Katolik sebanyak 112.830 orang, Hindu sebanyak 11.061 orang, Budha sebanyak 14.236 orang, dan agama lain sebanyak 1.403 orang. Penduduk Kota Bandung yang sebagian besar terdiri dari Suku Sunda, maka adat istiadatnya pun relatif masih tetap dipertahankan yaitu adat istiadat Sunda.

Tingkat Pendidikan masyarakat di Kota Bandung secara umum adalah setingkat SMU, Akademi/Kejuruan dan Perguruan Tinggi. Untuk mata pencaharian di wilayah ini mayoritas Golongan pribumi bekerja sebagai Pegawai Negeri, Swasta dan buruh serta sebagian kecil penduduk mata pencahariannya bercocok tanam /petani kecil-kecilan.

\section{Kondisi Sosial.}

Kegiatan kelompok Radikal Kanan di wilayah Jawa Barat umumnya dan Kota Bandung khususnya mulai muncul kembali dipermukaan dengan adanya beberapa kader radikal kanan yang intinya menolak Pancasila sebagai Ideologinya. Pertarungan antara Islam dengan sekulerisme terus terjadi di wilayah ini. Kapitalisme Liberal dan Sosialis Kanan (Soska), selalu menggunakan demokrasi sebagai jargon dan alat demi mewujudkan dan mempertahankan kemenangan politik. Dalam perekonomian, taraf hidup masyarakat di Jawa Barat pada umumnya dan di Kota Bandung pada khususnya sifatnya heterogen sehingga perbedaan tingkat hidup sebagian masyarakat antara pribumi dengan non pribumi cukup mencolok.

Pada kesempatan wawancara dengan Komandan Kodim 0618/BS Kota Bandung Letnan Kolonel Inf Ujang Sudrajad, disampaikan bahwa Kabupaten Bandung Barat dan Kota Cimahi sangat potensial dalam bidang pertahanan, karena wilayah ini merupakan pusat-pusat pendidikan militer khususnya TNI Angkatan Darat dari segala 
cabang kemiliteran sehingga merupakan potensi yang sangat baik dan siap pakai dalam rangka membantu pencegahan terorisme di wilayah. (Wawancara Mei, 2013)

\section{Peran Babinsa Dalam Kegiatan Deteksi Dini}

Dalam pembahasan Peran Babinsa Dalam Kegiatan Deteksi Dini ini, disampaikan tentang Pemahaman Aksi terorisme, Faktor Kepedulian Babinsa dalam kegiatan deteksi dini, Faktor Kemampuan Babinsa dalam kegiatan deteksi dini. Selanjutnya, dalam pembahasan tentang Pemahaman Aksi Terorisme diuraikan tentang aksi terorisme, faktor yang mendasari aksi terorisme, gambaran tentang pemahaman masalah terorisme dan pendataan tingkat pemahaman para Babinsa.

Aksi terorisme adalah serangan-serangan terkoordinasi yang bertujuan membangkitkan perasaan teror terhadap sekelompok masyarakat. Berbeda dengan perang, aksi terorisme tidak tunduk pada tata cara peperangan seperti waktu pelaksanaan yang selalu tiba-tiba dan target korban jiwa yang acak serta seringkali merupakan warga sipil. Kegiatan Terorisme mempunyai tujuan untuk membuat orang lain merasa ketakutan sehingga dengan demikian dapat menarik perhatian orang, kelompok atau suatu bangsa. Terorisme digunakan sebagai senjata psikologis untuk menciptakan suasana panik, tidak menentu serta menciptakan ketidakpercayaan masyarakat terhadap kemampuan pemerintah dan memaksa masyarakat atau kelompok tertentu untuk mentaati kehendak pelaku teror.

Untuk memahami lebih lanjut akar permasalahan dari terorisme itu sendiri, haruslah dipahami faktor-faktor pendukung yang menyertai tindakan terorisme. Beberapa faktor pendukung yang sering menyertai tindakan terorisme adalah sebagai berikut : Eksploitasi media, Melaksanakan operasi teror pada pemerintahan non otoriter, Penggunaan metode yang illegal, Persiapan, Perencanaan dan Dukungan.

Seminar Sekolah Sesko TNI Susreg Ke XXXV TA. 2008 menyatakan bahwa motif terjadinya terorisme adalah disebabkan beberapa faktor yang secara umum dipilahkan dalam 4 (empat) faktor mendasar, sebagai berikut: Membebaskan tanah air dari "penjajah", Memisahkan diri dari Pemerintah yang sah (Separatis), Sebagai proses sistem sosial yang berlaku (pembebasan dari sistem kapitalis). Menyingkirkan musuh-musuh politik". (Seminar Sekolah Sesko TNI Kursus Reguler Ke XXXV,2008:6)

Selain itu, posisi strategik Indonesia seperti letak, kekayaan sumber daya alam, jalur lintasan strategis dan lain-lain menjadikannya memiliki potensi sebagai ajang bagi kegiatan terorisme serta berkorelasi dengan jaringan terorisme internasional. Secara internal, Indonesia dengan berbagai aspek kehidupannya seperti aspek kekerabatan, aspek sosial psikologis dan aspek kehidupan ekonomi pun turut memberikan peluang yang sangat besar terhadap berkembangnya terorisme.

Hasil wawancara kepada para Danramil di wilayah Kodim 0618/BS Kota Bandung terhadap kemampuan Babinsa secara umum dapat dilihat pada kesimpulan awal di bawah ini, sebagai berikut:

Pertama, secara teori umumnya Babinsa tahu tentang tugas, fungsi dan kewenangannya untuk deteksi dini terorisme, namun dalam prakteknya belum sepenuhnya memahami dengan baik.

Kedua, kegiatan Babinsa dalam menghadapi terorisme sementara ini adalah 
hanya melakukan monitoring, selanjutnya melaporkan kepada Komando Atasannya.

Ketiga, kejelasan langkah-langkah konkrit bagi Babinsa dalam menghadapi terorisme masih sebatas kepada monitoring, dan belum disiapkan untuk bila berhadapan dengan terorisme. Umumnya para Babinsa sudah tahu tentang aksi terorisme, meskipun belum ke arah pemahaman khusus dan belum peka dengan gelagat negatif tersebut. Hal ini mengingat untuk kemampuan melacak teroris itu memerlukan ketrampilan khusus yang terus menerus harus dilatihkan.

Dalam pembahasan Faktor Kepedulian Babinsa Dalam Kegiatan Deteksi Dini ini, disampaikan tentang Pendapat tentang tingkat kepedulian Babinsa dalam kegiatan deteksi dini, dan tentang Pendataan tingkat kepedulian Babinsa dalam kegiatan deteksi dini. Sebagaimana telah diberitakan dalam Detiknews pada 9 Mei 2013, Karopenmas Mabes Polri, Brigjen Pol Boy Rafli Amar dalam konferensi pers di Mabes Polri, J1 Trunojoyo, Jakarta Selatan mengatakan bahwa Densus 88 menangkap 20 orang terduga teroris di Ciputat, Bandung, Kendal, dan Kebumen. Berdasarkan pengungkapan yang didapat dari aksi teror dan analisa selama ini, diketahui bahwa Bandung tidak hanya menjadi target terorisme domestik, namun juga dijadikan sebagai tempat perekrutan pelaku terorisme (recruiting pool).

Secara umum telah dilakukan langkahlangkah konkrit sebagai berikut:

Pertama, mengajak masyarakat untuk berperan aktif dalam melaksanakan siskamling.

Kedua, memonitor kegiatan pengajian / keagamaan dan hiburan serta kegiatan yang sifatnya pengumpulan masyarakat.
Ketiga, mencatat, mendata dan melaporkan setiap ada penduduk yang mencurigakan.

Keempat, apabila diperlukan ikut membantu RT/RW dalam pengecekan terhadap rumah-rumah kontrakan.

Pada dasarnya para Babinsa saat ini dalam mencegah penyusupan terorisme sudah merasa terlibat dalam membantu pencegahan terorisme. Perlunya masyarakat untuk diajak bekerjasama dalam melaksanakan siskamling bersama dalam rangka pencegahan penyusupan terorisme. Masyarakat juga memerlukan penataran tentang masalah terorisme, selanjutnya bila daerah yang diawasi cukup luas namun Babinsa tetap pegang prinsip yang kuat sebagai suatu keharusan untuk mengontrol secara rutin dan intens daerah binaannya.

Dalam pembahasan Faktor Kemampuan Babinsa Dalam Kegiatan Deteksi Dini ini, disampaikan tentang Pendapat tentang Kemampuan Babinsa dalam kegiatan deteksi dini, dan Pendataan tingkat kemampuan Babinsa dalam kegiatan deteksi dini.

Secara umum, kemampuan Babinsa dalam kegiatan deteksi dini guna pencegahan dan penanggulangan teroris masih terkendala karena belum jelasnya tugas, tanggung jawab dan kewenangan di bidang mengatasi terorisme. Dilihat dari kemampuan jumlah personil Babinsa di setiap wilayah khususnya Kodim 0618/BS Kota Bandung, dalam kegiatan operasional personil Babinsa dihadapkan kepada luas wilayah tanggung jawabnya memang sangat terbatas sekali.

Dari hasil wawancara dengan Danramil tingkat kemampuan para Babinsa dalam kegiatan deteksi dini aksi terorisme di wilayah Kodim 0618/BS Kota Bandung dalam 
pelaksanannya masih ada beberapa hal sebagai berikut: Pertama, tingkat SDM para Babinsa masih rendah. Kedua, sarana dan prasarana dalam membantu kelancaran penugasannya sangat terbatas. Ketiga, kemampuan intelejen tidak semua Babinsa memiliki kemampuan tersebut. Keempat, secara moralitas para Babinsa pada umumnya sangat baik terhadap tugas-tugas yang diberikannya.

Hasil Pengumpulan Data pada Kemampuan Babinsa dalam kegiatan deteksi dini guna pencegahan dan penanggulangan terorisme terhadap 151 responden Babinsa di wilayah Kodim 0618/BS Kota Bandung, dapat disimpulkan hasilnya sebagai berikut : Sebagian besar para Babinsa masih belum mempunyai kemampuan intelejen yang baik, sehingga sulit mengidentisifikasi para teroris, dan menyatakan bahwa sarana prasarana masih terbatas. Masih dirasakan bahwa kemampuan deteksi dini dirasakan sangat kurang. Disamping itu, juga masalah penting lainnya adalah tentang pendanaan kegiatan deteksi dini.

\section{Kendala Peran Babinsa Dalam Kegiatan Deteksi Dini}

Dalam bagian pembahasan ini, akan disampaikan Faktor Keamanan Lingkungan, Faktor komitmen dan kesadaran masyarakat, Faktor Tingkat Kapasitas Kelembagaan Babinsa, Faktor Tingkat Kerja Sama Penanganan, dan Faktor Tingkat Pemahaman Masyarakat.(Mbai, 2009)

Masalah keamanan wilayah harus ditangani secara tepat dan efektif dengan lebih mendahulukan tingkat penangkalan dan pencegahan. Upaya membangkitkan kepedulian masyarakat untuk ikut peran serta berpartisipasi terhadap lingkungannya secara tidak langsung akan cepat membantu terwujudnya stabilitas keamanan lingkungan. Mewujudkan adanya peran aktif masyarakat dan keikutsertaannya dalam tanggung jawab di bidang keamanan akan dapat membantu Babinsa dalam melaksanakan tugasnya.

Hasil dari wawancara dengan para Danramil tentang tingkat keamanan di wilayahnya dihadapkan pada kemungkinan menghadapi gangguan aksi terorisme sebagai berikut: Pertama, secara geografis wilayah ini cukup baik sebagai persembunyian terorisme oleh karena banyaknya tempat kos-kosan, perusahaan-perusahaan, kontrakan-kontrakan, perumahan. Kedua, tingkat keamanan khususnya pada masalah aksi terorisme di wilayah Kodim 0618/BSKota Bandung masih belum cukup kondusif. Ketiga, bagi warga, aturan bertamu lebih dari 24 jam secara prosedur harus melalui pemberitahuan kepada RT sebagai kebiasaan yang telah berlaku di lingkungan masyarakat. Keempat, hasil observasi maupun wawancara didapatkan bahwa masih adanya kerja sama dalam melaksanakan keamanan wilayah.

Hasil pengumpulan data tentang kemampuan babinsa dalam kegiatan deteksi dini tentang tingkat keamanan di lingkungan wilayahnya terhadap 151 responden Babinsa di wilayah Kodim 0618/BS Kota Bandung, dapat disimpulkan bahwa secara umum tingkat keamanan khusus di bidang terorisme untuk saat ini masih belum kondusif terutama dari masih belum bebas dari gangguan aksi terorisme. Pelaksanaan siskamling yang disampaikan responden dapat berjalan dengan baik setiap harinya. Sebagian responden menyatakan bahwa wilayahnya dimungkinkan sebagai tempat persembunyian teroris. Namun kehadiran para Babinsa dinyatakan bahwa 
menjadikan kekuatan moril tersendiri yang sangat berarti keberadaannya di tengah-tengah masyarakat.

Dalam pembahasan Faktor Komitmen dan kesadaran masyarakat ini, disampaikan tentang Pendapat tentang komitmen dan kesadaran masyarakat dan Pendataan tentang komitmen dan kesadaran masyarakat.

Meskipun Pemerintah Pusat dan Pemerintah Daerah telah berupaya melibatkan masyarakat dalam upaya meningkatkan kesadaran tentang bahaya aksi terorisme, namun pelaksanaanya masih belum optimal, karena sebagian besar masyarakat masih awam tentang adanya bahaya aksi terorisme dikarenakan bahwa ancaman terorisme mengarah kepada sasaran tertentu terutama orang asing, di samping itu peran organisasi masyarakat seperti LSM, LKMD serta organisasi profesi termasuk RT / RW belum dirasakan dapat terlibat secara langsung oleh Pemerintah Daerah ataupun aparat keamanan kota terkait.

Masyarakat kota pada umumnya telah mendelegasikan tugas Siskamling kepada para Satpam profesional yang digaji untuk tugas fokus pada tugas Siskamling, hal ini mengingat beban tugas penduduk yang bekerja seharian menjadi alasan pendukungnya, selain itu sosialisasi tentang terorisme masih belum menyentuh seluruh masyarakat. Sehingga masih perlu keterbukaan Polri apabila ada kemungkinan orang-orang yang patut dicurigai, sehingga masyarakat dapat juga berperan serta ikut membantu dalam pelaksanaan pengawasannya.

Bahwa masih ada wilayah yang masyarakatnya beranggapan bahwa masalah keamanan wilayah adalah tugas Kepolisian. Hasil penelitian terhadap 151 responden melalui kuisioner tentang tingkat komitmen dan kesadaran masyarakat untuk berpartisipasi dalam pencegahan terorisme dapat disimpulkan:Pada umumnya masyarakat telah mempunyai prosedur tetap tentang keamanan lingkungannya. Namun respon masyarakat mengindikasikan bahwa mereka tidak sepaham dengan teroris dan kuatir tempatnya dimasuki kelompok teroris, oleh sebab itu partisipasi mendukung program aparat keamanan sangat kuat. Di sisi lain masih ada aparat kelurahan belum mengerti benar bagaimana, dalam bentuk apa perannya dalam membantu pencegahan terorisme. Tingkat kesadaran hukum masyarakat cukup baik, masyarakat cukup aktif melaksanakan Siskamling dengan alasan bahwa terorisme merupakan musuh bersama.

Peran Babinsa sebagai ujung tombak aparat dalam mencegah terjadinya aksi terorisme saat ini dan ke depan, langkah yang harus dilakukan adalah terhadap polisi landasan hukumnya dan aturan pelibatan jajaran Babinsa itu dalam langkah aktif untuk ikut mengamankan wilayah terkecil di pedesaan, RT/RW dan Kelurahan-Kelurahan dalam mengamankan dan mencegah penyebaran jaringan aksi terorisme.

Hasil Pengumpulan Data pada Tingkat Kapasitas Kelembagaan Babinsa dalam pencegahan aksi terorisme terhadap 151 responden melalui kuisioner dapat disimpulkan sebagai bahwa hubungan antar aparat keamanan cukup baik dan cukup baik melaksanakan tugas dan fungsi masingmasing. Penanganan terhadap para teroris sebagian besar responden tidak menyetujui bahwa tugas tersebut hanya tugas Polri. Ada sebagian responden menyatakan bahwa keberadaan LSM belum cukup mampu membantu di bidang keamanan. Sebagian besar menyatakan bahwa kerja sama antar 
kelembagaan dalam setiap permasalahan telah mampu diatasi dengan baik, namun khususnya di wilayah Koramil 0618-05/ Kiaracondong masih belum maksimal.

Setiap level mulai dari tingkatan pembuat strategi sampai dengan pada level taktis harus secara terpadu dan terorganisir dengan baik sehingga dapat memberikan batasan terhadap tugas dan tanggung jawab pada setiap badan / institusi yang terlibat di TNI dan Kepolisian maupun masyarakat / LSM dalam melaksanakan tugas dan fungsinya, keadaan ini yang mempengaruhi aparat di lapangan melakukan koordinasi maupun melaksanakan tugasnya.Istilah perang melawan terorisme mutlak memerlukan kerja sama terpadu secara lintas instansi bahkan lintas negara, diperlukan suatu konsep operasi yang memadukan peran dan fungsi instansi-instansi pemerintah baik di tingkat pusat sampai ke daerah-daerah.

Hasil penelitian terhadap 151 responden Babinsa melalui kuisioner tentang kerja sama hubungan antar pihak terkait penanganan aksi terorisme, disampaikan bahwa masih ada sebagian responden menyatakan bahwa dalam penanganan pencegahan terorisme yang sesuai dengan Undang-Undang yang dipahami oleh Polri maupun TNI, ternyata juga belum mampu menyamakan persepsi dan tindakannya dalam mengatasi aksi terorisme. Sebagian besar responden menyatakan bahwa tingkat koordinasi di lapangan, masalah bagaimana cara yang terbaik dalam perannya masing-masing terhadap aksi terorisme masih dirasakan belum maksimal. Selanjutnya tentang penanganan permasalahan konflik di masyarakat, sebagian responden menyatakan masih dominan untuk diatasi oleh Polri.

Bila ditinjau dari bidang pemahaman, harus diakui peran serta masyarakat dalam mencegah aksi-aksi terorisme hingga saat ini masih belum memadai. Kondisi ini dapat dibuktikan dengan masih adanya anggota masyarakat dan atau kelompok-kelompok masyarakat yang terkesan memberikan dukungan, secara langsung maupun tidak langsung, terhadap aksiaksi terorisme. Bahkan tidak sedikit yang justru menganggap aksi terorisme merupakan salah satu implementasi dari pelaksanaan kewajiban agama yang tidak boleh dilarang.

Hasil wawancara dengan para Danramil tentang tingkat pemahaman masyarakat terhadap penanganan aksi terorisme secara umum masyarakat sangat tidak menyukai akan kebrutalan tindakan kelompok teroris, yang menurut masyarakat malah tidak mencerminkan bahwa kelompok teroris memiliki peri kemanusiaan dan keberadaban.

Hasil penelitian terhadap 302 responden MitraKaribmelaluikuisioner tentang pemahaman masyarakat dalam masalah aksi terorisme dapat disampaikan sebagai berikut: Pada umumnya masyarakat telah mempunyai pemahaman secara terbatas terhadap aksi terorisme. Namun respon masyarakat mengindikasikan bahwa mereka tidak sepaham dengan teroris dan kuatir tempatnya dimasuki kelompok teroris, oleh sebab itu partisipasi mendukung program aparat keamanan sangat kuat. Di sisi lain, masih ada aparat kelurahan belum mengerti benar bagaimana, dalam bentuk apa perannya dalam membantu pencegahan terorisme. Tingkat kesadaran hukum masyarakat cukup baik. Masyarakat cukup aktif melaksanakan Siskamling dengan alasan bahwa terorisme merupakan musuh bersama. Tokoh agama/adat saat ini cukup aktif memberikan penjelasan tentang masalah terorisme.

Dari hipotesa sementara sebelum dilaksanakan penelitian, ada beberapa faktor 
yang melatarbelakangi kurangnya partisipasi masyarakat dalam penanggulangan terorisme, di antaranya: Pertama, muncul anggapan bahwa pemberantasan aksi terorisme identik dengan perang terhadap agama tertentu; Kedua, adanya anggapan bahwa penanggulangan terorisme semata-mata tugas dan tanggung jawab Polri; Ketiga, masih berkembang anggapan bahwa pemberantasan terorisme merupakan wujud keberpihakan pemerintah Indonesia terhadap negara asing (Indonesia sebagai negara boneka); Keempat, adanya pandangan dari kelompok agama tertentu bahwa tindakan teror (seperti peledakan bom) yang ditujukan pada obyek-obyek tertentu, merupakan salah satu wujud dari menjalankan perintah agama dan dihalalkan; Kelima,munculnya rasa takut pada diri anggota masyarakat bahwa ketika mereka membantu aparat Polri dikhawatirkan akan memunculkan sikap balas dendam dari pelaku teror.

Data penelitian terhadap 302 responden Mitra Karib melalui kuisioner tentang peran aktif masyarakat terhadap pencegahan aksi terorisme disampaikan bahwa pada umumnya masyarakat telah mempunyai protap tentang keamanan lingkungannya. Namun respon masyarakat mengindikasikan bahwa mereka tidak sepaham dengan teroris dan kuatir tempatnya dimasuki kelompok teroris, oleh sebab itu partisipasi mendukung program aparat keamanan sangat kuat. Di sisi lain masih ada aparat kelurahan belum mengerti benar bagaimana, dalam bentuk apa perannya dalam membantu pencegahan terorisme. Tingkat kesadaran hukum masyarakat cukup baik. Masyarakat cukup aktif melaksanakan Siskamling dengan alasan bahwa terorisme merupakan musuh bersama. Tokoh agama/adat saat ini cukup aktif memberikan penjelasan tentang masalah terorisme.
Dari hipotesa sementara keterpaduan dalam penanganan yang dapat dilakukan dalam meningkatkan kewaspadaan sebagai salah satu cara mengurangi aksi terorisme adalah sebagai berikut: Pertama, adanya kesamaan pandangan dari seluruh elemen masyarakat dalam menyikapi aksi-aksi teror; Kedua, peran tokoh agama dan tokoh masyarakat untuk memberikan pencerahan kepada masyarakat perihal terorisme dalam perspektif yang benar harus semakin ditingkatkan agar pelaku terorisme tidak dapat mengembangkan pengaruhnya di Indonesia; Ketiga, revitalisasi terhadap partisipasi masyarakat dalam menjaga Kamtibmas; Keempat, Peran serta aparat pemerintah (Pemda) di berbagai tingkatan dalam memonitor setiap perpindahan penduduk untuk mencegah pelaku teror menyembunyikan identitasnya; Kelima, perlunya koordinasi yang sinergis antar instansi terkait; Keenam, pengenalan tentang terorisme sudah mulai diajarkan sejak usia dini; Ketujuh, kesiapsiagaan dari aparat keamanan terhadap peristiwa-peristiwa yang potensial menimbulkan konflik atau aksi terorisme harus selalu terjaga.

Hasil wawancara dengan para Danramil tentang tingkat keterpaduan dalam penanganan dan pencegahan aksi terorisme, dari tinjauan masyarakat dalam kegiatan mencegah aksi terorisme, secara umum masyarakat sangat mengharapkan adanya keterpaduan dari unsur aparat keamanan kota dan unsur LSM serta unsur masyarakat dalam kegiatan membantu mencegah aksi terorisme, namun masyarakat umumnya takut bila masyarakat dilibatkan lebih mendalam.

Data penelitian terhadap 302 responden masyarakat adalah berasal dari para Mitra Karib Kodim 0618/BS Kota Bandung, yang dilakukan 
melalui kuisioner tentang keterpaduan dalam penanganan dan pencegahan aksi terorisme. Adapun hasilnya akan disampaikan bahwa masyarakat mengharapkan penanganan terhadap aksi terorisme dilaksanakan secara terpadu.Masyarakat mengharapkan prosedur keterpaduan penanganan memiliki kekuatan hukum. Keterpaduan diharapkan melibatkan unsur masyarakat. Masyarakat mengharapkan dengan keterpaduan menjadi persatuan kokoh untuk menindak kejahatan aksi terorisme.

\section{Peluang Dan Kendala Babinsa}

Babinsa memiliki peluang sebagai berikut:. (1) Babinsa dan masyarakat telah mengetahui tentang aksi terorisme. (2) Babinsa telah memiliki kepedulian dalam pencegahan aksi terorisme. (3) Babinsa telah memiliki kemampuan secara terbatas dalam kegiatan deteksi dini. (4) Babinsa menyampaikan bahwa komitmen dan kesadaran masyarakat dalam berpartisipasi pencegahan aksi terorisme cukup baik.

Sementara itu, Babinsa memiliki kendala Sebagai berikut:. (1) tingkat keamanan di lingkungannya khusus di bidang terorisme masih belum cukup kondusif. (2) pada tingkat kapasitas kelembagaan untuk pencegahan aksi terrorisme dirasakan masih sangat kurang. (3) kerjasama penanganan antar pihak terkait masih dirasakan belum ada. (4) Peran aktif masyarakat dalam kegiatan pencegahan aksi terorisme masih belum optimal. (5) pendapat masyarakat sebagian besar menyatakan bahwa masalah keterpaduan dalam penanganan masih belum ada.

Dalam bagian pembahasan ini, akan disampaikan tentang Acuan gagasan Peningkatan Peran Babinsa, Kebijakan, dan Strategi. Keberhasilan dalam menanggulangi aksi terorisme terletak pada peran Babinsa dalam deteksi dini dan seluruh komponen bangsa untuk mencegah, menanggulangi dan memeranginya dengan semangat kebersamaannya, oleh sebab itu diperlukan kebijakan komprehensif yang mendasari strategi untuk keberhasilan pelaksanaan operasi pencegahan dan penanggulangan aksi terorisme di wilayah Kota Bandung.

Beberapa acuan gagasan untuk mendukung penyiapan kebijakan peningkatan peran Babinsa yang harus ditempuh sebagai berikut Pertama, memerlukan langkahlangkah konkrit. Kedua, memerlukan adanya sosialisasi. Ketiga, memerlukan perlengkapan dengan Sistem Pendukung. Keempat, memerlukan pemahaman terhadap tugas dan kewajiban. Kelima, Perlu koordinasi intens antar instansi pemerintah dan non pemerintah. Keenam, membina Babinsa agar memiliki kemampuan Daya tangkal. Ketujuh, membina Babinsa dan Masyarakat agar memiliki kepekaan terhadap kemungkinan Aksi Terorisme. Kedelapan, membentuk dan memberdayakan Forum Koordinasi Pencegahan Terorisme (FKPT).

Adapun kebijakan yang dapat diselenggarakan adalah: "Terwujudnya implementasi peran Babinsa dalam kegiatan deteksi dini melalui meningkatkan pembinaan moral sesuai nilai-nilai luhur Pancasila kepada masyarakat, meningkatkan penguasaan kegiatan lima kemampuan teritorial di lapangan bersama masyarakat, menumbuhkan semangat kebersamaan kesadaran akan bahaya potensial ancaman aksi terorisme, memberdayakan kapasitas kelembagaan, mengembangkan koordinasi yang intens antar instansi terkait guna membantu pencegahan dan penanggulangan aksi terorisme di wilayah". 
Strategi yang dapat diaplikasikan meliputi strategi jangka pendek dan strategi jangka panjang.Untuk meningkatkan kualitas dan kapasitas Babinsa bersama dukungan masyarakat dalam melakukan kegiatan deteksi dini. Strategi Jangka Pendek dengan sasaran : Pertama, meningkatkan pembinaan mental dengan upaya aktualisasi nilai-nilai luhur Pancasila; Kedua, strategi penguasaan kegiatan lima kemampuan teritorial dengan upaya peran aktif Babinsa bersama masyarakat; Ketiga, menumbuhkan kesadaran akan bahaya ancaman terorisme dengan upaya membangun semangat dan kesadaran masyarakat.

Untukmeningkatkan dan memberdayakan kapasitas kelembagaan, mengembangkan koordinasi antar pemerintah pusat daerah, tokoh agama, tokoh adat, tokoh pemuda, ormas, unsur TNI/Polri, media massa serta civitas akademika dalam upaya bersama mencegah berkembangnya radikal aksi terorisme. Strategi Jangka Panjang dengan sasaran : Pertama, memberdayakan kapasitas kelembagaan Babinsa dapat dilakukan dengan upaya pada kapasitas kelembagaan; Kedua, mengembangkan koordinasi antar instansi terkait dapat dilakukan dengan upaya mengadakan koordinasi intens antar instansi.

\section{SIMPULAN}

Peran Babinsa dalam deteksi dini ditinjau dari pemahaman, kepedulian dan kemampuan Babinsa masih belum optimal. Kendala Babinsa dalam kegiatan deteksi dini adalah tingkat keamanan khusus terorisme masih belum kondusif, tingkat kapasitas kelembagaan dirasakan masih sangat kurang ; Kerjasama penanganan antar pihak terkait masih belum ada, peran aktifmasyarakat masih belum optimal dan masalah keterpaduan penanganan antar pihak terkait masih belum ada. Berdasarkan hasil peluang dan kendala yang didapat dari analisis data penelitian, kebijakan yang harus diprogramkan adalah Terwujudnya implementasi peran Babinsa dalam kegiatan deteksi dini melalui meningkatkan pembinaan moral sesuai nilai-nilai luhur Pancasila kepada masyarakat, meningkatkan penguasaan kegiatan lima kemampuan teritorial di lapangan bersama masyarakat, menumbuhkan semangat kebersamaan kesadaran akan bahaya potensial ancaman aksi terorisme, memberdayakan kapasitas kelembagaan, mengembangkan koordinasi yang intens antar instansi terkait guna membantu pencegahan dan penanggulangan aksi terorisme di wilayah.

Diperlukan suatu pembinaan yang terprogram secara menyeluruh di lingkungan masyarakat seiring dengan dibentuknya FKPT terkait tentang bahaya aksi terorisme dan akibat yang ditimbulkan agar ada kesamaan pola pikir, pola sikap dan pola tindak guna terwujudnya keamanan di wilayah masingmasing sesuai tanggung jawabnya. Agar secara rutin dilaksanakan pertemuan untuk aktualisasi kerja sama antar aparat terkait dan masyarakat, dalam penyelenggaraan sistem keamanan lingkungan di wilayah secara terkoordinir, dalam rangka upaya deteksi dini dan cegah dini dari ancaman aksi terorisme yang dipimpin oleh Pimpinan daerah.

\section{DAFTAR PUSTAKA}

Departemen Pertahanan RI. 2008. Buku Putih Pertahanan Indonesiaa, Jakarta: Dephan RI.

Djelantik, Sekarwarsini. 2010. Tujuan PsikoPolitis. Peran Media, Kemiskinan, dan Keamanan Nasional. Bandung: Citra Aditya Bakti. 
Komarudin Simanjuntak -- Peran Babinsa Dalam Kegiatan Deteksi Dini Guna Pencegahan Aksi Terorisme (Relevansi Di Wilayah Kodim 0618/BS Kota Bandung)

Hendropriyono, AM. 2009. Terorisme dalam

Kajian Filsafat Analitik : Relevansinya dengan Ketahanan Nasional. Yudhagama

Mbai, Ansyaad. 2009. Kebijakan Penanggulangan Terorisme di Indonesia. Seminar dan Lokakarya Sespim Polri, Bdg, 29 Okt 2009.

Purwanto, Wawan H.,2009. Satu Dasawarsa Terorisme di Indonesia, Jakarta : Grafindo Khazanah Ilmu.
Sesko TNI, 2008. Seminar Sekolah Sesko TNI kursus Reguler ke XXXV, Bandung: Stensil

Sarwono, SW. 2012. Terorisme Di Indonesia Dalam Tinjauan Psikologi, Tanggerang: Pt. Pustaka Alfabet.

\section{Wawancara:}

1. Letkol, Inf. Ujang Sudrajad: Mei 2013 